\title{
Ko te kai rapu ko ia te kite (One who seeks will find)
}

by Philip Harvey

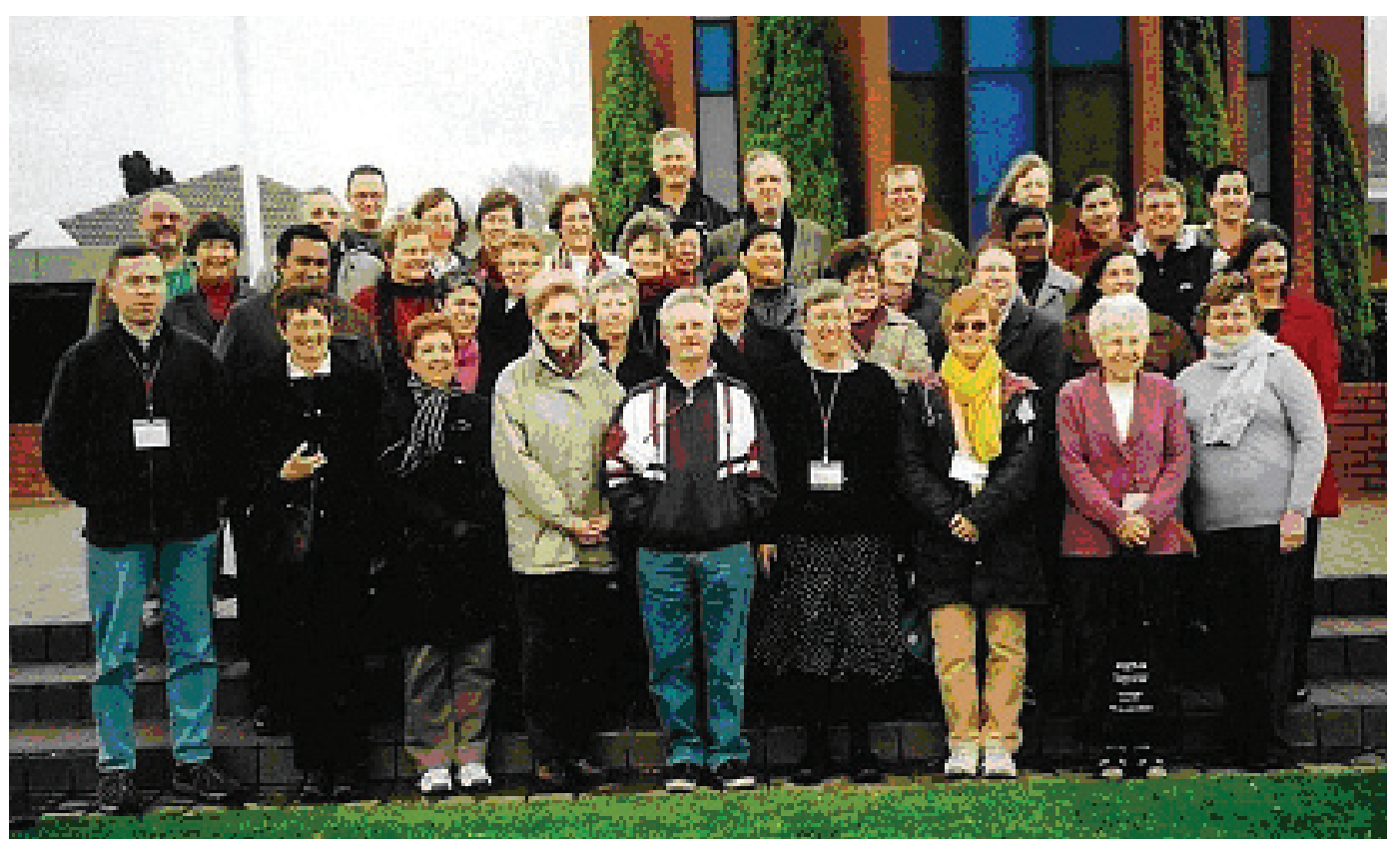

The President's Summary at Practicalities of the TwentyThird ANZTLA Conference, held at Scots College, Strathmore Park, Wellington, Aotearoa New Zealand from Thursday 10th to Sunday 13th of July, 2008.

his year's traditional preconference cataloguing session was led by Chris Todd (National Library of New Zealand). Resource Description and Access (RDA) heralds major changes to our practices. RDA changes our working concepts, with encoding and display, content and carrier, and online tools. Punctuation becomes an option rather than an AACR requirement. The necessity of RDA is seen in the replacement of the General Material Designator [GMD] with Content Type, e.g. notated music, moving images; Carrier Type, e.g. online resource, audio disc; and Media Type, e.g. computer, video. Chris said that very broadly speaking, RDA structure fell into two categories, the recording attributes of entities, i.e. most of $\mathrm{AACR}$, and recording relationships between entities,i.e.all the added entities. What elsehas to happen? MARC changes and library systems 


\section{"What do you do with 400 copies of the King James Bible?"}

developments. The full draft of RDA is ready for release in October, we hope, and the review period ends in January 2009 with publication of the first release later in the year.

For a keynote address with a difference just invite Penny Carnaby (New Zealand National Librarian). To use one of her own favourite terms, it was more like a mashup. New Zealand is a very joined up country, she announced, talking about the digital linkup of the country happening in December. Penny brought along some leading questions to aim at a panel of guests, as well as delegates. The guests were Paddy Plunket (Parliamentary Librarian, Wellington), Elizabeth Banks (Wellington Regional Council Library), and an old friend of ANZTLA's, Gary Gorman (Victoria University of Wellington). What got you into librarianship?, was the first question, at which Penny said lust, lust for a librarian she met during postgraduate studies. Indeed, lust seemed to be the main force driving people to become librarians generally, followed by an incredible taste for floral clothing. The three people on the tartan couch seemed to agree, as did a large proportion of the delegates. Penny's worldview is infectious. Gary Gorman asked, Are librarians losing their status? What is a librarian? (Maybe one to come back to next year.) The question of the hour was thrown down thunderously, What do you do with 400 copies of the King James Bible? How many do you need? Answers got murkier by the minute involving fire, then council tips, and worse. Penny was shocked. Leaving them out for users was a calmer and more useful solution. The panel had to admit it was a valid question when asked, Does cataloguing have a future?

Everyone piled on the bus Friday morning for the first of several stunning scenic rives along the harbour. We met Chris Todd on her home turf, who this time gave more of an historical overview of RDA for all delegates. It is not AACR3 but a different set of rules. RDA data is intended to support user tasks, be compatible with existing library catalogues, and be independent of encoding formats. AACR2 is translated into twenty-four languages. In the non-Anglo world the Europeans have ad some input to RDA plans, but maybe not much elsewhere. What can we do at home? Ask our system vendors what they're planning re: RDA. Watch the RDA website for information about releases. Watch OCLC's position, what OCLC says will influence what vendors do next.

Robyn East (National Library of New Zealand) introduced us to Maori subject headings and the major project, just completed, of an online thesaurus, Nga Upoko Tukutuku. The Thesaurus is online. This is the latest product of time to which Robyn is associated, being also coeditor of the massive triumph known as 'Publications in Maori before 1900'. The Thesaurus lists key terms, names and language with special and unique use in Maori, all entries that do not exist in LCSH. LCSH is captive to its own terms and 
structures and cannot represent the subtlety of meanings in Maori vocabulary. Robyn and her colleague Ann Reweti (Maori Librarian, Wellington City Libraries) addressed the contentious problem of Maori dialects, where main terms for a subject take preference over local terms. This can lead to an homogenisation of the language in printed form. Australians looked on with envy at the bibliographical results of a national bicultural policy.

Kete Horowhenua is the latest shape-change from the masterminds of the New Zealand town of Levin. Rosalie Blake demonstrated 'Kete - telling our stories together', a free source website www.horowhenua.kete.net.nz Thus far Kete can publicise and archive events, maintain businesses on the net, showcase artists, work with the performing arts, assist with schools, record history through photos, oral history, genealogical charts, and that's only the outline. There is a special ANZAC component for keeping soldiers' memories alive and saving stories and images from the military past.

Before lunch at the Salvation Army College of Mission in Upper Hutt, the Association had its annual portrait taken. As we learnt later from Te Papa's resident

photographer Michael Hall, people in the middle are thinner than people at the edges, so remember to find a flattering position at the Canberra photo shoot.

After lunch was something else again. G. K. (Bill) Tito is a self-declared Surgeon General to Literature, in common language a bookbinder. Bill binds sets of Dickens but didn't think anyone reads Dickens anymore; however, you have to have read Charles Dickens to appreciate that Bill is someone from out of Dickens. It was bloody huge, mate! Bill has perfected the practice of public confession and the public is well warned. Though Bill has failed more than once to be elected mayor, if becoming mayor is about promoting your own interests then half of Upper Hutt might be bookbinding by now. From a librarian's perspective, is that a bad thing? One of my favourite Tito aphorisms was, "Binders don't make books look new, they make them look old." A favourite piece of insider knowledge in this session came from a Canberra delegate: "Fortress Press always falls apart."

Judith Bright (John Kinder Theological Library, Auckland), Mark Hangartner (University of Auckland Library), Judith Curtis (TheologyHouse, Christchurch), and Kerrie Stevens (Harvest Bible College, Victoria) led a sparkling and original session on future issues within the profession, within libraries, and in information. If I was to provide an indication of the projected needs for the library for the next 25 years, what would that include? To quote responses to just that one question, delegates' responses included the following. More staff and more specialist staff. Broadband?, Stephen Morton (Garden City College, Queensland) invented the word Hugeband. Power plugs. More and more space, 
whatever. Searches that are federated and easy. Future-proof technology. Get the library out there! Judith Bright brought things back to earth by saying that five year plans are about the most sensible way forward. Mark Hangartner observed that in 25 years the institutions themselves may have changed entirely.

Next morning the same Mark Hangartner ran through the choice and installation of Bibleworks7. The lecture theatre was then turned into a photographic workspace. Michael Hall (The Museum of New Zealand Te Papa Tongarewa, Wellington) gave an illuminating, in more ways than one, presentation of contemporary photographic practice. Digital is quite fragile, archiving images is sensitive work. Documenting the work is important: work out a file system first. We heard about 'the digital cliff': without hard copy we need to think about long-term storage, its advantages, hazards, and pitfalls. Ourwebsites and communications will benefit from increased awareness of these skills. We learnt the techniques for best results, e.g. a white diffusing cocoon for photographing silver and jewelry, or the raking light used to highlight serrated and woven surfaces.

After the conference dinner the Association enjoyed a ceilidh, led by Helen Greenwood (John Kinder Theological Library, Auckland). This is now a feature of New Zealand conferences. A group of Scottish dancers performed Helen's original dance step entitled 'Bridie Harvey', an event that will last permanently in the mind of the present President. We all danced The Old Brown Jug, Gay Gordon, The Kingston Flyer, and many others. Kerrie Stevens took many images using a focussed aperture with delay for those 'heal and toes', checking her white balance and avoiding the daylight setting. Wendy Davis (Adelaide Theological Library) tooted her flute, the Queensland Chapter invented a pantomime that gave a whole new meaning to the Lamington Cake, and Lynn Pryor (Churches of Christ Theological College, Victoria) led us through sentimental favourites. James Bhagwan (Davuilevu Methodist Theological College, Fiji) and Nalini Premadish (Pacific Theological College, Fiji) ("the two worst singers in Fiji", said James) led us through a Fijian farewell song. During one dance the ghosts of ceilidhs past tried to join in by jumping from the rafters; the scrim lost its grip. Jean Malcolm, musician and dancer, maintained a professional posture while the capers continued undiminished. As they say in the classics, a good time was had by all!

Sunday morning, after the ecumenical service, delegates saw and heard two very different illustrated talks on the subject of text and image. Kevin Waldie (Good Shepherd College, Auckland) began by showing how Scripture reveals and conceals its meaning.Infilmlikewise,weinterpretnarrative touncoverandidentify meaning.Selected trailersandexcerptsfrom recentmoviesshowed how filmmakers manufacture particular effects both to underscore 
and drive narrative meaning. Mervyn Duffy (also of Good Shepherd College) examined the iconography of a fourteenth century book of hours made for and owned by Catherine, Duchess of Cleves. He paid reverence to 'Making the hours' (2006) by Eamon Duffy (no relation), influential in his method. Catherine's book intertwined biblical stories with the seasons, the owner returning each year to the festivals and rounds of the life she knew. Serious intent and good-humoured observation of human behaviour are main standards of the illuminated paintings on each page.

The New Zealand Chapter have perfected the art of longdistance conference planning. First a conference in Napier, then one outside Auckland, and now a conference in Wellington where there are only two theological libraries. How do they do it? The size of this year's Conference Committee gives an idea: Lesley Utting, Judith Bright, Judith Curtis, Margaret Grigg, Mark Hangartner, Denise James, Liz Tisdall, Carol Wills, and Helen Greenwood. All of these Committee members ask me to thank in particular the other member of the team, Beverley McKenzie, who took on the lioness's share of the work - a huge undertaking at the local level, and working furthermore from Upper Hutt. And we would like to thank all of these people for their great dedication, for helping achieve what has been an enjoyable, informative, productive and successful ANZTLA conference. 